\title{
The Activity of Anti-Oxidide of Etil Acetate Soluble Fractions from Extract of Kedayan Roots (Aristolochia Papillfolia Ding Hou)
}

\author{
Novermawati ${ }^{1}$, Muh. Amir ${ }^{2}$, Islamudin ${ }^{3}$ \\ 1,2,3 Faculty of Teacher Training and Education, Mulawarman University, Samarinda, East Kalimantan, Indonesia \\ nurergaamir@yahoo.com
}

\begin{abstract}
Kedayan roots (Aristolochia papillfolia Ding hou) is phytomedicine that used conventionally by peoples as antidotum. This research aims to know antioxidant activity of ethyl acetate soluble fraction from kedayan roots extract. Fractionation method that used is solid-liquid extraction with ethyl acetat as solven so that produced fraction that dissolve in ethyl acetate, than fractionated again with liquid vacuum chromatography with eluent $n$-hexane and ethyl acetat with some proportion of each solven and produced fraction $A(5: 5)$, fraction $B(4: 5)$, fraction $C(3: 5)$, fraction $D(2: 5)$, fraction $E(1: 5)$, and fraction $F$ (0:5). Antioxidant activity assay used DPPH (2,2-diphenyl-1picrylhydrazyl) as radical substance and determined by visible spectrophotometre. Than data analyzed with linier regression to know $\mathrm{IC}_{50}$. The result of fraction $\mathrm{C}$ from kedayan roots (Aristolochia pap illfolia Ding hou) in ethyl acetate fraction have antioxidant activity with $\mathrm{IC}_{50} \mathbf{1 3 9 , 1 1} \mathrm{ppm}$.
\end{abstract}

Keywords--Kedayan roots (Aristolochia papillfolia Ding hou), antioxidant, $\mathbf{I C}_{50}$.

\section{INTRODUCTION}

Currently medicinal plants become one of the alternative drugs selected by the public. This is because medicinal plants have no great side effects when compared with modern drugs made from synthetic chemicals. One of the medicinal plants is root plant kedayan. Kedayan root is a typical plant of North Kalimantan, especially Malinau District. The root of Kedayan has been used by the Dayak community as a medicinal plant.

The root of kedayan is a wood-shaped root that spreads on the trees, has a light brown, segmented, elongated and usually lives in forest areas, climbing, and lowland. Empirically often used by society as a medicine, such as toxic antidote, neutralize insect poison, snake venom and all kinds of poisonous animal bites, food poisoning, diarrhea, toothache and also can be used to neutralize liquor (alcohol). The use of root kedayan can be used in the form of thin slices and mixed with warm water.

The use of Kedayan root is believed empirically by the public as a toxic antidote, but there is no scientific research about medicinal plants of Kedayan root. Therefore researchers interested in doing research to determine the secondary metabolite class, how chromatographic profiles of chemical compounds, and antioxidant activity in root plants kedayan.
Free radicals are reactive, and if not activated will damage the cell-forming macromolecules, i.e. proteins, carbohydrates, fats, and nucleic acids, which can lead to degenerative diseases. Antioxidants are a substance that can protect the body (body parts) from free radical compounds. This free radical compound is a compound that has free electrons, so look for free electron pairs or reactive to oxidizable compounds such as lipids, body proteins, carbohydrates, and others. The antioxidant compounds of the plant are usually phenolic compounds and their derivatives. These compounds are powerful antioxidants $[1,3,6]$.

However, in-depth research on this plant has not yet been discovered. This study aims to determine the activity, and as a scientific information for researchers and society of property owned by medicinal plants Roots kedayan. Therefore, it is necessary to test the activity of the root fraction of kedayan (Aristolochia papillfolia Ding hou) which is the soluble fraction of ethyl acetate.

\section{METHOD}

\section{A. Material}

The samples studied were root of root plant (Aristolochia papillfolia Ding hou), the materials used were aluminum foil, ethyl acetate, filter paper, ethanol, methanol, silica gel, ethanol, n-hexane, DPPH, KLT plate.

\section{B. Tool}

The equipment used in this study was stirring and spoon rods, glass chutes (Pyrex $\left.{ }^{\circledR}\right)$, porcelain cups, $10 \mathrm{~mL}$ measuring flask, $50 \mathrm{~mL}$ pepper flask, micropipet (Boeco®) 100 and 1000 $\mu \mathrm{L}$, analytical balance Hammer $\left.{ }^{\circledR}\right)$, oven (Froilabo $\left.{ }^{\circledR}\right)$, vortex

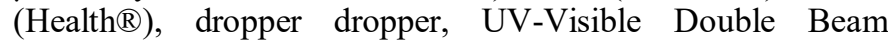
(Dynamica $\left.{ }^{\circledR}\right)$ spectrophotometer, reaction tube (Pyrex ${ }^{\circledR}$ ), reaction tube rack, $50 \mathrm{~mL}$ (Pyrex ${ }^{\circledR}$ ) erlenmeyer, basket, vial bottle, capillary pipe, hot plate (Stuart), sprayers, tweezers, stirers, jars, spatel, vacuum chromatography, ruler, cutter, water bath (Memmert), rotary evaporator (Buchi), chamber. 


\section{Extraction}

Samples of $1 \mathrm{Kg}$ extracted using maseration method soaked with ethanol solvent for 3-5 days were once stirred then filtered. The obtained extract solution was evaporated well using a rotary evaporator until a viscous extract was obtained. The viscous extract is then evaporated into the water bath.

\section{Fractionation}

The ethanol extract of 24 grams was extracted by liquidsolid using an ethyl acetate solvent. Acquired ethyl acetate fraction having 2 separations, ie soluble ethyl acetate and insoluble ethyl acetate. The fraction taken for the test is the soluble fraction of ethyl acetate.

\section{E. Fractionation by Thin Layer Chromatography}

A total of 9 grams of soluble ethyl acetate fraction were dissolved with ethyl acetate and then added with $10 \mathrm{~g}$ of crude silica, the solvent was evaporated with the aid of a rotary evaporator until powder was formed. After that, proceed with a vacuum liquid chromatography fractionation process using $6 n-$ hexane solvent ratio: ethyl acetate from low to high polarity. In aliri gradually obtained each fraction of fraction $\mathrm{A}(5: 5)$, fraction $\mathrm{B}(4: 5)$, fraction of C (3: 5), fraction $\mathrm{D}(2: 5)$, fraction $\mathrm{E}(1: 5)$, and fraction $\mathrm{F}(0: 5)$.

\section{F. Antioxidant Activity Testing by KLT Method}

Testing of antioxidant activity using KLT method with nhexane motion phase: ethyl acetate (3: 3), while the stationary phase is silica gel $60 \mathrm{~F} 254$ with $8 \mathrm{~cm}$ plate length. After the process of tracing the KLT plate was sprayed with a $0.1 \%$ DPPH solution in methanol. The incidence of whitish yellow stains after 30 minutes later showed a positive antioxidant [4].

\section{G. Making Stock Solution and Variation of Concentration of Ethyl Acetate Fluid Fraction}

Preparation of stock solution of soluble ethyl acetate fraction is $1000 \mathrm{ppm}$ in $10 \mathrm{~mL}$. A total of 0.01 grams of fraction were dissolved with methanol to a limit of $10 \mathrm{~mL}$. The concentration variations used 5 concentrations in $10 \mathrm{~mL}$ were $10 \mathrm{ppm}(0.1 \mathrm{~mL}), 50 \mathrm{ppm}(0.5 \mathrm{~mL}), 100 \mathrm{ppm}$ (1 mL), $150 \mathrm{ppm}$ (1.5 mL), $200 \mathrm{ppm}(2 \mathrm{~mL})$.

\section{H. Testing of IC50 Value Fraction C Soluble Ethyl Acetate}

Antioxidant activity testing was performed with DPPH on the soluble fraction of ethyl acetate. The DPPH test is performed by measuring the maximum wavelength and absorbance. After that, a 5\% concentration of soluble ethyl acetate fraction of $10 \mathrm{ppm}, 50 \mathrm{ppm}, 100 \mathrm{ppm}, 150 \mathrm{ppm}, 200$ ppm was done. Each fraction concentration was dissolved with methanol with 3 replications. Taken $2 \mathrm{~mL}$ fraction is put into a closed reaction tube then added $2 \mathrm{~mL}$ DPPH solution homogenized using vortex. After 30 minutes the absorbance was measured at $\lambda=510 \mathrm{~nm}$, calculated percent of antioxidant activity, IC50 value and data analysis using linear regression [5].

\section{RESULTS \& DISCUSSION}

In this research, the antioxidant activity (In Autographic TLC) of ethyl acetate soluble fraction using DPPH method is done. The antioxidant activity of the compounds was carried out qualitatively by spraying DPPH and IC50 calculations. Measurement of antioxidants by DPPH method is a simple method of measuring antioxidants, fast and does not require as many reagents as other methods. The results of measurement by the DPPH method show the general antioxidant capability of the sample, not based on the inhibited radical type [2]. DPPH which is a free radical molecule with a purple color can turn into a stable compound with yellow color by reaction with antioxidants, where antioxidants give one electron to DPPH resulting in damping of DPPH free radicals. The eluted fractions were then sprayed with a $0.1 \%$ DPPH solution, after the TLC plate stripping process and spraying. The incidence of whitish yellow stains after 30 minutes later showed a positive antioxidant [4].

The result shows that fraction having antioxidant activity is fraction of $\mathrm{C}$, fraction $\mathrm{E}$, and fraction of $\mathrm{F}$. In fraction of $\mathrm{C}$ the appearance of yellow round spots is in the middle of TLC plate, this result indicates that the separation of compound in eluent of $\mathrm{C}$ fraction on elution result shows more compound separation good and not tails. In the fraction of E, and the fraction of $\mathrm{F}$, the appearance of yellow spots extends to the purple background, which indicates the separation of the compound is poor because of the accumulation of the compound at the separation of the two eluents. Based on the results of testing the antioxidant activity obtained a better eluent separation is the fraction and followed by calculation of IC50 value.

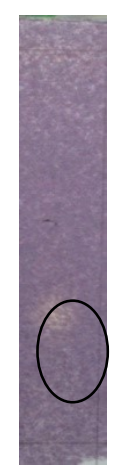

FRAKSI C

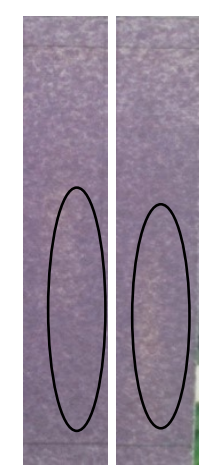

FRAKSI E FRAKSI F
Fig. 1. Results of antioxidant activity of ethyl acetate soluble fraction after DPPH spraying

Determination of IC50 Value as Antioxidant Activity of Ethyl Acetate Fluid Fraction Testing of antioxidant activity with IC50 value parameter used is fraction of $\mathrm{C}$. The reason for choosing fraction of $\mathrm{C}$ is based on elution process on TLC plate showed better and not tailed compound separation then followed by spraying of $0.1 \% \mathrm{DPPH}$ solution showed positive having antioxidant activity with the appearance of yellow round spots is in the middle of the TLC plate so it can be assumed that only one compound gives the activity as an antioxidant and facilitates the development of further research 
that is at the isolation or separation stage to obtain the pure compound.

Test results Antioxidant activity of soluble fraction of ethyl acetate fraction $\mathrm{C}$ [soluble fraction solution in eluen n-hexane: ethyl acetate (3: 5)] root kedayan (Aristolochia papillfolia Ding hou) with DPPH method can be seen in Table I and Fig. 1.

TABLE I. TEST RESULT THE SOLUBLE FRACTION OF ETHYL ACETATE FRACTION C SOLUTION OF SOLUBLE FRACTION IN ELUEN N-HEXANE: ETHYL ACETATE (3: 5)] KEDAYAN ROOT (ARISTOLOCHIA PAPILLFOLIA DING HOU)

\begin{tabular}{|c|c|c|c|c|c|}
\hline No & $\begin{array}{l}\text { Concentra- } \\
\text { tion }\end{array}$ & $\begin{array}{l}\text { Average } \\
\text { Absorption }\end{array}$ & $\begin{array}{l}\% \\
\text { Antioxidant } \\
\text { Activity }\end{array}$ & $\begin{array}{l}\text { Linear } \\
\text { Regression } \\
\text { Equation }\end{array}$ & IC50 \\
\hline 1 & $10 \mathrm{ppm}$ & 0,339 & $7,95 \%$ & \multirow{5}{*}{$\begin{array}{l}Y=0,292 x \\
+9,38 \\
r=0,98\end{array}$} & \multirow{5}{*}{$\begin{array}{l}139,1 \\
1 \mathrm{ppm}\end{array}$} \\
\hline 2 & $50 \mathrm{ppm}$ & 0,276 & $25,12 \%$ & & \\
\hline 3 & $100 \mathrm{ppm}$ & 0,204 & $44,55 \%$ & & \\
\hline 4 & $150 \mathrm{ppm}$ & 0,168 & $54,29 \%$ & & \\
\hline 5 & $200 \mathrm{ppm}$ & 0,133 & $63,84 \%$ & & \\
\hline
\end{tabular}

The calculation used in the determination of radical catch activity is the value of IC50 (Inhibition concentration 50\%). This value describes the concentration of test compounds that can capture radicals by $50 \%$. IC50 values in this study were obtained by using a linear regression equation which expresses the relationship between the sample concentrations (test compound) with the symbol (x) with the average radical catch activity with the symbol (y) of the replication series of measurements. The maximum wavelength is obtained from the maximum absorbance of $510 \mathrm{~nm}$ where this wavelength will be used in antioxidant testing.

Testing of antioxidant activity of soluble ethyl acetate root fraction of kedayan (Aristolochia papillfolia Ding hou) using DPPH method gave IC50 value of $139,11 \mathrm{ppm}$. At concentration $139,11 \mathrm{ppm}$ showed concentration of ethyl acetate soluble fraction (microgram / milliliter) which able to inhibit oxidation process by $50 \%$, or able to reduce free radical that is equal to $50 \%$. The relationship between concentrations with antioxidant activity, where the increasing concentration of ethyl acetate soluble fraction hence the ability to dampen the greater. The concentration can show the amount of active compound dissolved, therefore the higher the concentration the more the amount of active compound in the test solution, with the increasing amount of active compound is then increased also\% antioxidant activity (DPPH damping). The smaller the IC50 value means the higher the antioxidant activity. Specifically, a compound is said to be an antioxidant if the IC50 value is less than $200 \mathrm{ppm}[3,5]$.

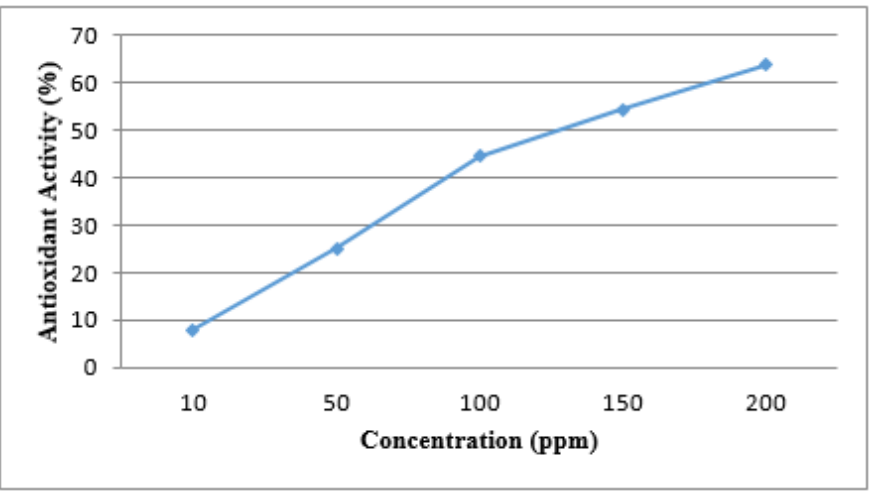

Fig. 2. Graph of Effect of Concentration on Antioxidant Activity The soluble fraction of ethyl acetate

Figure 2 shows that there is a correlation between concentration and percent of antioxidant activity, where the higher concentration of ethyl acetate soluble fraction, the higher the antioxidant activity percentage is $9.55 \%$ to $19.43 \%$. The linear regression equation has a positive $b$ value, thus indicating that the percent value curve of antioxidant activity is an increasing curve. The coefficient $b$ is the linear regression coefficient and denotes the average change of the $y$ variable for each variable change $\mathrm{x}$. The results of the data can be said fraction soluble ethyl acetate has antioxidant activity because it has IC50 value less than $200 \mathrm{ppm}$ that is equal to $139,11 \mathrm{ppm}$.

\section{CONCLUSION}

Based on the purpose of research and discussion, the authors draw conclusions, namely TLC autographic testing of the soluble fraction of ethyl acetate root extract Kedayan (Aristolochia pap illfolia Ding hou) has antioxidant activity characterized by the presence of yellow spot with purple background. The soluble fraction of ethyl acetate of kedayan root extract (Aristolochia pap illfolia Ding hou) at fraction C having IC50 value is $139,11 \mathrm{ppm}$.

\section{REFERENCES}

[1] Heinrich, Michael. 2008. Farmakognosi dan Fitoterapi. Penerbit EGC: Jakarta.

[2] Juniarti, D. Osmeli dan Yuhernita. 2009. Kandungan Senyawa Kimia, Uji Toksisitas (Brine Shrimp Lethality Test) dan Antioksidan (1,1diphenyl-2-pikrilhydrazyl) Dari Ekstrak Daun Saga (Abrus precatiorius 1.). Makara Sains.

[3] Molyneux, P. 2004. The Use Of The Stable Free Radical Diphenylpicrylhydrazyl (DPPH) For Estimating Antioxidant Activity. J. Sci. Technol.

[4] Ngan, D.H., 2005. "Bioactivities and Chemical Constituents of A Vietnamese Medicinal Plant Jasminium Subtriplinerve Blume (Che Vang)". Master Thesis. Departemen of Chemistry and Life Science, Roskilde University.

[5] Sudjana. 2002. Metoda Statistika. Tarsito : Bandung.

[6] Wagner, H. and S. Bland. 1996. Plant Drug Analysis; A Thin Layer Chromatography Atlas. 2nd Edition. Berlin Heidelberg: Springer. 